\title{
Resistance to Pitting Corrosion in Steels Based on the Fe-Cr-Ni-C System
}

\author{
Mérilin Cristina dos Santos Fernandes ${ }^{a}$; Sandra Nakamatsu ${ }^{b}$; Ana Laura Polississo Rueda ${ }^{\text {, Jordan }}$ \\ Junqueira Souza ${ }^{a}$,Stephania Capellari De Rezende ${ }^{a}$, Lucíola Lucena de Souza ${ }^{a}$,
}

Neide Aparecida Mariano *

\author{
${ }^{a}$ Universidade Federal de Alfenas - UNIFAL, Campus Avançado de Poços de Caldas, Rod. José Aurélio \\ Vilela, BR 267-Km 533, Cidade Universitária, Poços de Caldas, 377015-400, MG, Brazil \\ ${ }^{b}$ Instituto de Física e Química, Universidade Federal de Itajubá - UNIFEI, Avenida BPS, 1303, Itajubá, \\ 37500-903, MG, Brazil
}

Received: December 12, 2016; Revised: March 05, 2017; Accepted: April 21, 2017

\begin{abstract}
This study aimed to investigate the effects of difference in nickel content and the tempering temperatures on the corrosion resistance in $13 \mathrm{Cr} 2 \mathrm{Ni} 0.1 \mathrm{C}$ and $13 \mathrm{Cr} 1 \mathrm{Ni} 0.15 \mathrm{C}$ steels. Results showed that passive film in $13 \mathrm{Cr} 2 \mathrm{Ni} 0.1 \mathrm{C}$ steel is formed more quickly at the lowest and highest tempering temperature $\left(650^{\circ} \mathrm{C}\right.$ and $\left.750^{\circ} \mathrm{C}\right)$ but the lowest tempering temperature $\left(650^{\circ} \mathrm{C}\right)$ showed better resistance to corrosion pitting. There was passive film formation and pitting corrosion in all tempering temperatures of the $13 \mathrm{Cr} 1 \mathrm{Ni} 0.15 \mathrm{C}$ steel and changes in tempering temperature does not significantly alter polarization curves, showing similar behavior to steel $13 \mathrm{Cr} 2 \mathrm{Ni0} .1 \mathrm{C}$ tempered at $650^{\circ} \mathrm{C}$.
\end{abstract}

Keywords: Heat treatment, Corrosion, Martensitic stainless steel, Pitting, FeCrNiC

\section{Introduction}

The study of corrosion marine environments is particularly interesting for low carbon martensitic stainless steels because of the wide use of these steels in equipment applied in the petrochemical industry and oil production in offshore platforms ${ }^{1-3}$. Localized pitting corrosion is the most common type of corrosion and difficult to control in marine environment, especially in deep waters, which are characterized by high concentration of chlorides, low $\mathrm{O}_{2}$ concentration, presence of corrosive gases - such as $\mathrm{CO}_{2}$ and $\mathrm{H}_{2} \mathrm{~S}$ - microorganisms and other dissolved salts ${ }^{4}$.

The superior corrosion properties of stainless steels result from the formation of a thin oxide film on surface, called as the passive film ${ }^{5}$. Pitting corrosion occurs when the passive film breaks down in the presence of aggressive ions, such as chloride ions, resulting in the local dissolution and cavities on the metal surface ${ }^{6,7}$. Once the pites is formed, it can initiate and propagate a crack along the material thickness and lead to a catastrophic failure ${ }^{8}$.

The stability of the passive film has a direct impact on pitting resistance ${ }^{4}$, the microstructural characteristics of the alloy alter the properties of the passive film and the pitting resistance, representing a feature of particular interest ${ }^{9}$. Thus, the microstructural changes caused by certain heat treatments applied to stainless steels can result in the formation of surface films that exhibit different protection capabilities to resist to pitting corrosion.

* e-mail: neideaparecidamariano@gmail.com
Martensitic stainless steels are always quenched at temperatures $200^{\circ} \mathrm{C}$ higher than final temperature of austenite formation and tempered near the initial temperature of austenite formation ${ }^{10}$. At different tempering temperatures, the precipitates or carbides of the tempered martensitic stainless steels are different and result in significant property changes since the pits tend to occur near inclusion and precipitated phases ${ }^{11-13}$. Rodrigues et al observed a typical microstructure of a martensitic matrix in a supermartensitic stainless steels and find small precipitates $(40 \mathrm{~nm})^{14}$. In this way, it is necessary to use a temperature range for heat treatment.

The influence of tempering temperature on the corrosion resistance of low carbon martensitic stainless steels in marine environments is still poorly understood, even though the importance of these steels and the microstructural transformations observed after heat treatments are widely studied $^{15-18}$. Thus, this study aimed to investigate the effect of the tempering temperature on the corrosion resistance of $13 \mathrm{Cr} 2 \mathrm{Ni0} .1 \mathrm{C}$ and $13 \mathrm{Cr} 1 \mathrm{Ni0} .15 \mathrm{C}$ steels.

\section{Materials and Methods}

The steels were produced in an electric arc furnace with argon-oxygen decarburization (AOD). The chemical compositions obtained by inductively coupled plasmaatomic emission spectrometer (ICP/AES), for these steels are shown in Table 1.

The austenitic transformation temperatures $\left(\mathrm{A}_{\mathrm{cl}}\right.$ and $\left.\mathrm{A}_{\mathrm{c} 3}\right)$ and martensitic transformation temperatures $\left(\mathrm{M}_{\mathrm{i}}\right.$ and $\left.\mathrm{M}_{\mathrm{f}}\right)$ obtained by dilatometry by Mendonça et. $\mathrm{al}^{19}$ are shown in Table 2 . 
Table 1. Chemical compositions of the steels (wt.\%).

\begin{tabular}{lllllll}
\hline Steel & $\% \mathrm{C}$ & $\% \mathrm{Si}$ & $\% \mathrm{Mn}$ & $\% \mathrm{Cr}$ & $\% \mathrm{Ni}$ & $\% \mathrm{Mo}$ \\
\hline 13Cr2Ni0.1C & 0.09 & 0.92 & 0.75 & 13.00 & 2.05 & 0.15 \\
$13 \mathrm{Cr} 1 \mathrm{Ni0.15C}$ & 0.15 & 1.02 & 0.75 & 13.00 & 1.03 & 0.08 \\
\hline
\end{tabular}

Table 2. Temperatures of the steels transformations.

\begin{tabular}{lcccc}
\hline Steel & $\mathrm{A}_{\mathrm{c} 1}\left({ }^{\circ} \mathrm{C}\right)$ & $\mathrm{A}_{\mathrm{c} 2}\left({ }^{\circ} \mathrm{C}\right)$ & $\mathrm{M}_{\mathrm{i}}\left({ }^{\circ} \mathrm{C}\right)$ & $\mathrm{M}_{\mathrm{f}}\left({ }^{\circ} \mathrm{C}\right)$ \\
\hline 13Cr2Ni0.1C & 804 & 863 & 262 & 179 \\
13Cr1Ni0.15C & 750 & 820 & 231 & 163 \\
\hline
\end{tabular}

By means of $\mathrm{A}_{\mathrm{c} 3}$ values was selected the quenching temperature of $1000^{\circ} \mathrm{C}$ for two hours with subsequent tempering for the two steels. Similarly, with $\mathrm{A}_{\mathrm{cl}}$ it was possible to propose a temperature range for the tempering treatment also for two hours. Thus, the tempering temperatures used were $650^{\circ} \mathrm{C}$, $700^{\circ} \mathrm{C}$ and $750^{\circ} \mathrm{C}$, for $13 \mathrm{Cr} 2 \mathrm{Ni} 0.1 \mathrm{C}$ steel and $600^{\circ} \mathrm{C}, 650^{\circ} \mathrm{C}$, $700^{\circ} \mathrm{C}$ and $750^{\circ} \mathrm{C}$ for $13 \mathrm{Cr} 1 \mathrm{Ni} 0.15 \mathrm{C}$ steel. These samples were cooled in air. Heat treatments were performed in a muffle furnace without protective atmosphere and temperatures were monitored by using Chromel-Alumel thermocouple.

Corrosion behavior was evaluated by cyclic potentiodynamic polarization method using a potentiostat Metrohm model Autolab/PGSTART302 connected to a typical electrochemical cell with a saturated calomel electrode (SCE) used as a reference electrode, a platinum plate employed as counterelectrode and the working electrode made from the steels studied. Electrochemical measurements were performed in triplicate for each condition. An aerated solution of synthetic marine medium with a concentration of $60,000 \mathrm{ppm}$ at room temperature $\mathrm{Cl}$, prepared according to ASTM D1141-98, was used. After immersion in the solution, the samples were subjected to conditions of open circuit potential (OCP). The potentiodynamic curves were measured at a potential scan rate of $1 \mathrm{mV} / \mathrm{s}$ with direction reversal when impacted the anodic current density of $10^{-3} \mathrm{~A} / \mathrm{cm}^{2}$.

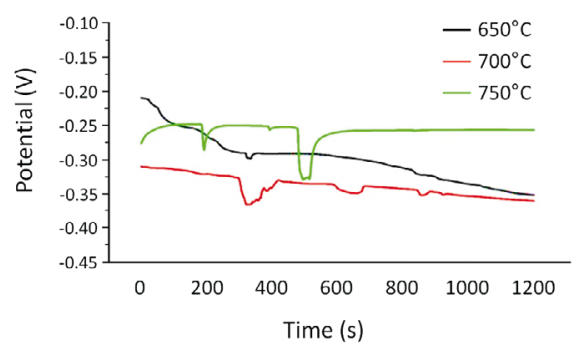

(a)
Microstructural characterization was carried out using optical microscopy. The surface etching was achieved with modified Behara at room temperature, in accordance with ASTM E3-11.

\section{Results and Discussion}

The open circuit potential (OCP) and cyclic potentiodynamic polarization (PPC) curves obtained for $13 \mathrm{Cr} 2 \mathrm{Ni} 0.1 \mathrm{C}$ steel are shown in Figure 1 while the electrochemical parameters are presented in Table 3.

The OCP curve towards more positive potentials suggests formation of a passive film on the metal surface, while the reduction of potential suggests generalized corrosion. Figure 1a shows that in the tempering temperatures of $650^{\circ} \mathrm{C}$ and $700^{\circ} \mathrm{C}$ the OCP curves move towards more negative potentials with increasing time, but for the sample tempered at $750^{\circ} \mathrm{C}$ the OCP curve stabilized at less negative potentials indicating formation of the passive film. Figure $1 \mathrm{~b}$ shows that the passivation region is noticeable in all curves but the sample tempered at $650^{\circ} \mathrm{C}$ shows a less clear passivation region.

In Table 3 it is possible seeing a significant difference between the corrosion potential $\left(\mathrm{E}_{\text {corr }}\right)$, pitting potential $\left(\mathrm{E}_{\mathrm{pit}}\right)$ and current passivation $\left(\mathrm{I}_{\mathrm{pp}}\right)$ values at each tempering temperature, but the values are very close in case of the protection potential $\left(\mathrm{E}_{\text {prot }}\right)$. More negatives values of pitting potential lead to lower resistance to pitting corrosion. Thus, the sample tempered at $650^{\circ} \mathrm{C}$ shows the highest resistance to pitting corrosion.

Figure 2 shows the micrograph by optical microscopy of the $13 \mathrm{Cr} 2 \mathrm{Ni} 0.1 \mathrm{C}$ steel tempered. The black arrows indicate the martensitic matrix and white arrows indicate the delta ferrite phase undissolved derived from gross melting. It is possible to identify grain boundaries filled with the martensitic phase shaped laths in all tempering temperatures.

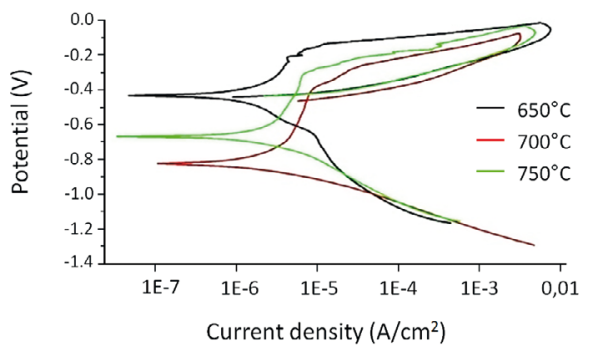

(b)

Figure 1. Curves obtained in the corrosion test in synthetic marine environment to $60,000 \mathrm{ppm}$ Cl- of the 13Cr2Ni0.1C steel. (a) OCP and (b) CPP.

Table 3. Electrochemical parameters of the $13 \mathrm{Cr} 2 \mathrm{Ni} 0.1 \mathrm{C}$ steel.

\begin{tabular}{lcccc}
\hline Tempering Temperature & $\mathrm{E}_{\text {corr }}(\mathrm{V})$ & $\mathrm{E}_{\mathrm{pit}}(\mathrm{V})$ & $\mathrm{I}_{\mathrm{pp}}\left(\mathrm{A} / \mathrm{cm}^{2}\right)$ & $\mathrm{E}_{\text {prot }}(\mathrm{V})$ \\
\hline $650^{\circ} \mathrm{C}$ & -0.439 & -0.188 & $5.12 \mathrm{E}-6$ & -0.438 \\
$700^{\circ} \mathrm{C}$ & -0.767 & -0.292 & $6.55 \mathrm{E}-6$ & -0.434 \\
$750^{\circ} \mathrm{C}$ & -0.527 & -0.240 & $5.42 \mathrm{E}-6$ & -0.431 \\
\hline
\end{tabular}


In the micrograph of the sample tempered at $700^{\circ} \mathrm{C}$ is possible to observe large ferrite delta islands, this leads to a decrease of pitting corrosion potential $\left(\mathrm{E}_{\mathrm{pit}}=-0.292 \mathrm{~V}\right)$, because delta ferrite presence produces detrimental effects on corrosion resistance ${ }^{20}$. In the case of sample tempered at $750^{\circ} \mathrm{C}$ ferrite delta phase is more dissolved and consequently the pitting potential increases $\left(\mathrm{E}_{\mathrm{pit}}=-0.240 \mathrm{~V}\right)$ while in the sample tempered at $650^{\circ} \mathrm{C}$ it is highest $\left(\mathrm{E}_{\text {pit }}=-0.188 \mathrm{~V}\right)$ due to refinement of the martensitic laths (needles-like structures) in the sample tempered at $750^{\circ} \mathrm{C}$ that lead to create more active sites facilitating pitting corrosion.

The open circuit potential (OCP) and cyclic potentiodynamic polarization (PPC) curves obtained for $13 \mathrm{Cr} 1 \mathrm{Ni0} .15 \mathrm{C}$ steel are shown in Figure 3 while the electrochemical parameters are presented in Table 4.
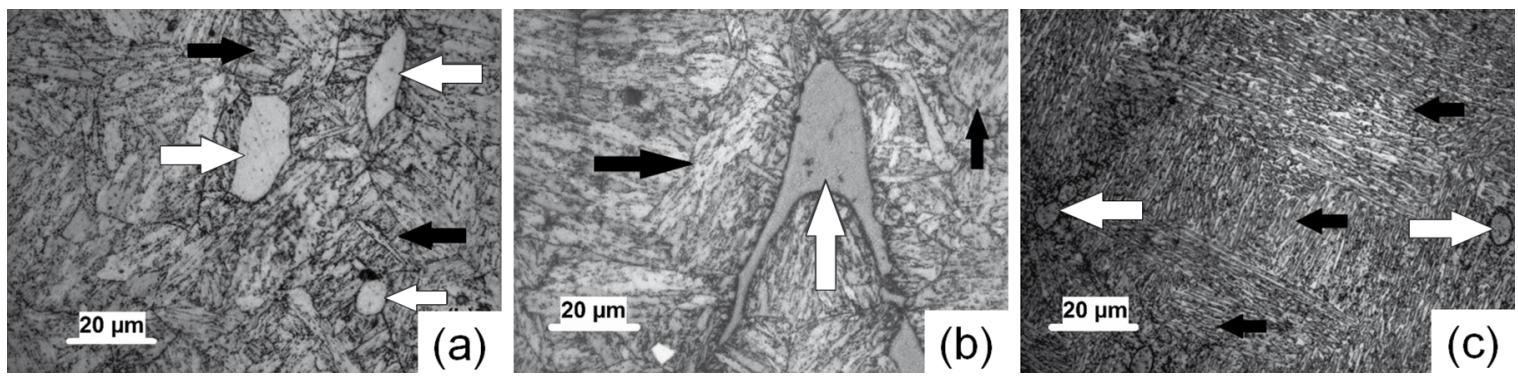

Figure 2. Micrograph by optical microscopy of the $13 \mathrm{Cr} 2 \mathrm{Ni} 0.1 \mathrm{C}$ steel tempered at (a) $650^{\circ} \mathrm{C}$, (b) $700^{\circ} \mathrm{C}$ and (c) $750^{\circ} \mathrm{C}$.

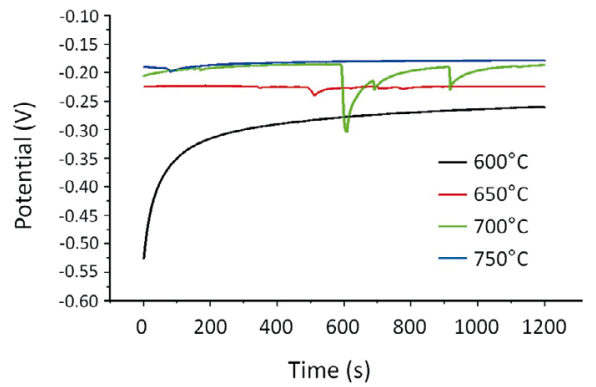

(a)

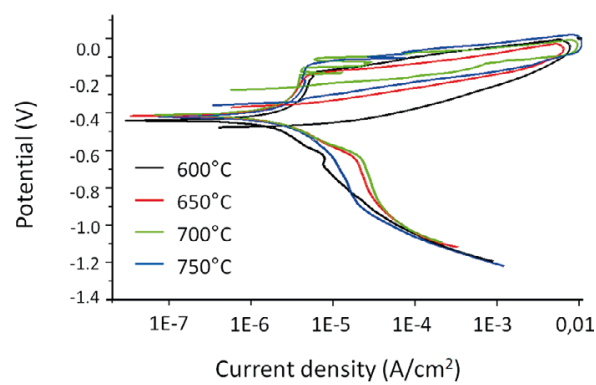

(b)

Figure 3. Curves obtained in the corrosion test in synthetic marine environment to $60,000 \mathrm{ppm} \mathrm{Cl}$ - of the 13Cr1Ni0.15C steel. (a) OCP and (b) CPP.

Table 4. Electrochemical parameters of the $13 \mathrm{Cr} 1 \mathrm{Ni} 0.15 \mathrm{C}$ steel.

\begin{tabular}{lcccc}
\hline Tempering Temperature & $\mathrm{E}_{\text {corr }}(\mathrm{V})$ & $\mathrm{E}_{\mathrm{pit}}(\mathrm{V})$ & $\mathrm{I}_{\mathrm{pp}}\left(\mathrm{A} / \mathrm{cm}^{2}\right)$ & $\mathrm{E}_{\mathrm{prot}}(\mathrm{V})$ \\
\hline $600^{\circ} \mathrm{C}$ & -0.461 & -0.161 & $5.00 \mathrm{E}-6$ & -0.449 \\
$650^{\circ} \mathrm{C}$ & -0.455 & -0.179 & $4.21 \mathrm{E}-6$ & -0.330 \\
$700^{\circ} \mathrm{C}$ & -0.419 & -0.139 & $3.80 \mathrm{E}-6$ & -0.309 \\
$750^{\circ} \mathrm{C}$ & -0.420 & -0.140 & $4.15 \mathrm{E}-6$ & -0.331 \\
\hline
\end{tabular}
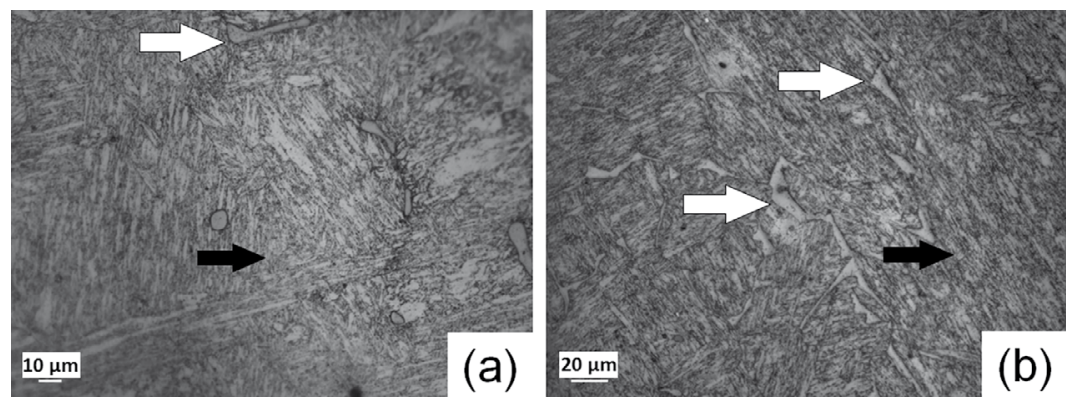

Figure 4. Micrograph by optical microscopy of the $13 \mathrm{Cr} 1 \mathrm{Ni} 0.15 \mathrm{C}$ steel tempered at (a) $650^{\circ} \mathrm{C}$ and (b) $700^{\circ} \mathrm{C}$. Black arrows indicate the martensitic matrix and white arrows indicate the delta ferrite phase. 
In Figure $3 \mathrm{a}$ it is possible seeing that all OCP curves show the tendency to stabilize in potentials with more positive values, indicating the formation of the passive film in all samples. Furthermore, it notes the curves show the same positive hysteresis tendency indicating the occurrence of localized pitting corrosion. Another feature present in Figure $3 \mathrm{a}$ is a passive region, which for some samples is not a straight line because occurred a slow oxidation. The polarization curves in Figure $3 b$ showed no significant difference in their positions, which confirmed the formation of passive film and pitting localized corrosion in all tempering temperatures.

According to Table 4 the values of the electrochemical parameters found for the samples with different tempering temperatures were very close, so that the variation of the tempering temperature was not significant in the corrosion characteristics of this steel corrosion characteristics. From the micrographs of the $13 \mathrm{Cr} 1 \mathrm{Ni} 0.15 \mathrm{C}$ steel shown in Figure 4, it is observed that with increasing of the tempering temperature the martensitic matrix becomes more refined and orderly, but the delta ferrite does not have a preferred site.

Comparing the electrochemical parameters of the two steels, it is possible to notice that $13 \mathrm{Cr} 2 \mathrm{Ni} 0.1 \mathrm{C}$ steel has the most favorable value at tempering temperature of $650^{\circ} \mathrm{C}$ while all values found for the electrochemical parameters of $13 \mathrm{Cr} 1 \mathrm{Ni} 0.15 \mathrm{C}$ steel are close to the best value found to the first steel.

\section{Conclusions}

The tempering temperature used in $13 \mathrm{Cr} 2 \mathrm{Ni} 0.1 \mathrm{C}$ steel influences in the electrochemical parameters. In the temperature of $650^{\circ} \mathrm{C}$ and $750^{\circ} \mathrm{C}$ the passive film is formed more quickly and in the tempering temperature at $650^{\circ} \mathrm{C}$ has a better corrosion resistance performance. In $13 \mathrm{Cr} 1 \mathrm{Ni} 0.15 \mathrm{C}$ steel the curves OCP and PPC obtained in the corrosion tests indicated passive film formation and occurrence of localized pitting corrosion in all tempering temperature used, in order that the tempering temperature was not significant in steel corrosion characteristics. The electrochemical parameters of the latter steel showed values close to those found in the temperature of $650^{\circ} \mathrm{C}$ of the first steel.

\section{Acknowledgements}

The authors acknowledge to FAPEMIG, CNPq, CAPES and FAPESP.

\section{References}

1. Turnbull A, Grifiths A. Review: Corrosion and cracking of weldable $13 \mathrm{wt} \% \mathrm{Cr}$ martensitic stainless steels for application in the oil and gas industry. Corrosion Engineering Science Technology. 2003;38(1):21-50.
2. Yin ZF, Wang XZ, Liu L, Wu JQ, Zhang YQ. Characterization of corrosion product layers from $\mathrm{CO}_{2}$ corrosion of $13 \mathrm{Cr}$ stainless steel in simulated oil field solution. Journal of Materials Engineering and Performance. 2010;20(7):1330-1335.

3. Ma XP, Wang LJ, Liu CM, Subramanian SV. Microstructure and properties of $13 \mathrm{Cr} 5 \mathrm{Ni} 1 \mathrm{Mo} 0.025 \mathrm{Nb} 0.09 \mathrm{~V} 0.06 \mathrm{~N}$ super martensitic stainless steel. Materials Science and Engineering: A. 2012;539:271-279.

4. Anselmo N, May JE, Mariano NA, Nascente PAP, Kuri SE. Corrosion behavior of supermartensitic stainless steel in aerated and $\mathrm{CO}_{2}$-saturated synthetic seawater. Materials Science and Engineering: A. 2006;428(1-2):73-79.

5. Mu LJ, Zhao WZ. Investigation on carbon dioxide corrosion behaviour of $13 \mathrm{Cr}$ stainless steel in simulated stratum water. Corrosion Science. 2010;52(1):82-89.

6. Park JO, Matsch S, Böhni H. Effect of Temperature and Chloride Concentration on Pit Initiation and Early Pit Growth Stainless Steel. Journal of the Electrochemical Society. 2002;149(2):B34-B39.

7. Marcelin S, Pébère N, Régnier S. Electrochemical characterisation of a martensitic stainless steel in a neutral chloride solution. Electrochimica Acta. 2013;87:32-40.

8. Caines S, Khan F, Shirokoff J. Analysis of pitting corrosion on steel under insulation in marine environments. Journal of Loss Prevention in the Process Industries. 2013;26(6):1466-1483.

9. Gervasi CA, Méndez CM, Bilmes PD, Llorente CL. Analysis of the impact of alloy microstructural properties on passive films formed on low-C 13CrNiMo martensitic stainless steels. Materials Chemistry and Physics. 2011;126(1-2):178-182.

10. Song Y, Li X, Rong L, Yiyi L. Anomalous phase transformation from martensite to austenite in Fe-13\%Cr-4\%Ni-Mo martensitic stainless steel. Journal of Materials Science \& Technology. 2010;26(9):823-826

11. Lu SY, Yao KF, Chen YB, Wang MH, Liu X, Ge X. The effect of tempering temperature on the microstructure and electrochemical properties of a $13 \mathrm{wt} . \% \mathrm{Cr}$-type martensitic stainless steel. Electrochimica Acta. 2015;165:45-55.

12. Seifert M, Wieskämper D, Tonfeld T, Huth S. Corrosion properties of a complex multi-phase martensitic stainless steel depending on the tempering temperature. Materials and Corrosion. 2015;66(11):1290-1298.

13. Ryan MP, Williams DE, Chater RJ, Hutton BM, Mcphail DS. Why stainless steel corrodes. Nature. 2002;415:770-774.

14. Rodrigues C, Lorenzo P, Sokolowski A, Barbosa C, Rollo J. Development of a Supermartensitic Stainless Steel Microalloyed with Niobium. Journal of ASTM International. 2006;3(5):1-5.

15. Bilmes PD, Solari M, Liorente CL. Characteristics and effects of austenite resulting from tempering of $13 \mathrm{Cr}-\mathrm{NiMo}$ martensitic steel weld metals. Materials Characterization. 2001;46(4):285-296.

16. Calliari I, Zanesco M, Dabalà M, Brunelli K, Ramous E. Investigation of microstructure and properties of a Ni-Mo martensitic stainless steel. Materials \& Design. 2008;29(1):246-250. 
17. Wang P, Lu PS, Xiao NM, Li DZ, Li YY. Effect of delta ferrite on impact properties of low carbon $13 \mathrm{Cr}-4 \mathrm{Ni}$ martensitic stainless steel. Materials Science and Engineering: A 2010;527(13-14):3210-3216.

18. Lei X, Feng Y, Zhang J, Fu A, Yin C, Macdonald DD. Impact of Reversed Austenite on the Pitting Corrosion Behavior of Super $13 \mathrm{Cr}$ Martensitic Stainless Steel. Electrochimica Acta. 2016;191:640-650.

19. Mendonça R, Cronemberger MER, Santos MT, Mariano NA. The effect of the tempering in martensitic stainless steels:
13Cr4Ni0.02C, 13Cr2Ni0.1C E 13Cr1Ni0.15C. Proceedings of the 68th ABM International Annual Congress; 2013 Jul 30Ago 2; Belo Horizonte, MG, Brazil. São Paulo: ABM; 2013. p. 4203-4209.

20. Kim SH, Moon HK, Kang T, Lee CS. Dissolution kinetics of delta ferrite in AISI 304 stainless steel produced by strip casting process. Materials Science and Engineering: A. 2003;356(1-2):390-398. 